Relations industrielles

Industrial Relations

\title{
Kruse, Douglas L., Profit Sharing : Does it Make a Difference?
}

\section{Richard J. Long}

Volume 49, numéro 4, 1994

Syndicats et restructuration économique

Unions and Economic Restructuring

URI : https://id.erudit.org/iderudit/050981ar

DOI : https://doi.org/10.7202/050981ar

Aller au sommaire du numéro

\section{Éditeur(s)}

Département des relations industrielles de l'Université Laval

\section{ISSN}

0034-379X (imprimé)

1703-8138 (numérique)

Découvrir la revue

Citer ce compte rendu

Long, R. J. (1994). Compte rendu de [Kruse, Douglas L., Profit Sharing: Does it Make a Difference ?]. Relations industrielles / Industrial Relations, 49(4),

861-863. https://doi.org/10.7202/050981ar

Tous droits réservés (C) Département des relations industrielles de l'Université Laval, 1994
Ce document est protégé par la loi sur le droit d'auteur. L’utilisation des services d'Érudit (y compris la reproduction) est assujettie à sa politique d'utilisation que vous pouvez consulter en ligne.

https://apropos.erudit.org/fr/usagers/politique-dutilisation/ 
constituer des lectures intéréssantes dans le cadre de cours relatifs à la formation professionnelle ou à l'analyse du marché du travail.

Marie-Thérèse CHICHA

Université de Montréal

Profit Sharing: Does it Make a Difference? by Douglas L. KRUSE, Kalamazoo, Mich., The W.E. Upjohn Institute for Employment Rechearch, 1993, 289 p., ISBN 0-88099-138-0 and ISBN 0-88099-137-2 (pbk).

The purpose of this book is to analyze the existing empirical evidence on the impact of profit sharing on company performance and employment stability, while adding the results of a comprehensive empirical study conducted by the author himself. The question posed by the book title is an important one, as companies increasingly turn to profit sharing as a means of improving their performance, and social policy analysts argue for profit sharing as a means of preserving employment and enhancing employment stability.

Does profit sharing really do either? Kruse tackles this question in five chapters. The first chapter defines the concept and discusses its recent growth and current prevalence in the United States. The second chapter extends this analysis by examining the specific motives that companies have for adopting profit sharing, and identifies the types of firms and circumstances under which profit sharing is likely to be implemented.

Chapters 3 and 4 are the real meat of this book, as they focus, in turn, on the two main issues of interest - productivity and employment stability. Chapter 3 begins by examining the existing evidence linking profit sharing to company productivity. Previous studies suggest such a link but the causal direction is not clear. Furthermore, most of the existing studies do not deal with the possibility that profit sharing firms may have other policies that are in fact responsible for increased productivity.

Based on longitudinal study of 250 U.S. firms that have profit sharing, and 250 that do not, and controlling for possible confounding variables, Kruse concludes that profit sharing can lead to improved company productivity, but this is dependent on the nature of the plan and size of firm. For example, plans that base their payout on a percentage of wages show no favourable effects (which is just what theory would suggest, since these are not true profit sharing plans). In terms of firm size, profit sharing was most effective in small firms, but was also effective in very large firms. However, it is not clear whether this latter result is due to firm size per se, or to a difference in the nature of profit sharing plans across the different size categories of firms.

Chapter 4 examines the evidence on whether, by reducing the fixed component of labour costs, profit sharing can enhance employment stability within firms, as Weitzman has argued (The Share Economy, Cambridge, Harvard University Press, 1994). Of course, this argument assumes that profit sharing substitutes, to some extent at least, for fixed wages, which is not at all clear. Historically, most proponents of profit sharing have argued that it should serve as a bonus on top of competitive wages. 
The evidence in fact suggests that employees in profit sharing firms do earn higher total income than employees in comparable non-profit sharing firms. But if profit sharing really does raise productivity, the stability argument could still apply, since profit sharing firms would have a higher productivity per fixed labour dollar, and the profit share may substitute for fixed wages for the incremental productivity.

The available data on the stability question are scanty, but based mainly on his own data analysis, Kruse concludes that profit sharing may improve employment stability, but only in firms which have more recently adopted profit sharing, which were more likely to have utilized profit sharing to substitute for fixed wages. He also finds that, consistent with theory, only those profit sharing plans based on a fixed percentage of profits tend to produce stability effects.

In Chapter 5, Kruse summarizes his conclusions, and suggests some implications for various interested parties. For companies, Kruse suggests that profit sharing can bring productivity improvements, but only under the right circumstances with the right kind of plan. For workers and unions, Kruse argues that profit sharing may benefit them through better employment stability and higher total income. For public policy makers, Kruse suggests that the implications depend on their motives. If productivity is the focus, then some type of information dissemination role for government may be justified, but not direct financial support. But if employment stability is the focus, then tax incentives for certain types of plans may well be justified, since profit sharing may contribute to the public good through the reduction of unemployment. But all of these suggestions are tentative, since Kruse does not consider the existing evidence, even coupled with his own, as conclusive.

Overall, the book succeeds in its rather narrow objective of providing the most comprehensive analysis to date of the empirical evidence relating profit sharing to productivity and employment stability. However, it is somewhat disappointing that, despite all this effort, the results are so ambiguous. But this is not really surprising, for a variety of reasons.

One problem is that the independent variable - profit sharing — is not sharply defined. Kruse included in his study many types that would not really qualify as profit sharing. His criterion question was "Does your company have a profit-sharing plan for employees other than top management?' No definition of profit sharing was provided, leaving it up to the respondent to decide whether their firm qualified or not. Thus, there is no guarantee that all companies included in the "profit sharing" group really belonged there. Beyond that, plans restricted to management were apparently included, as were plans where the payout bore little direct relationship to profitability. For example, a substantial number of the so-called profit sharing firms based their annual payout on a percentage of payroll, not profits.

Even for those plans which could legitimately be categorized as "profit sharing", there are many diverse motives for introducing them, one of the most common being to serve as a pension plan. In many cases, productivity increases are an incidental goal, at best. Considering all of this. and the fact that productivity itself can be influenced by so many factors, it would be very difficult to find a strong relationship between profit 
sharing and productivity, even if such an effect truly exists. Future research needs to deal with these problems.

There are at least two other limitations of this book. One is that it focuses almost exclusively on productivity and stability as dependent variables. While these are perhaps the most important consequences of profit sharing, there are many others - such as reduced absenteeism and turnover, or increased employee interest in the company that may well justify its implementation. Second, the book devotes relatively little attention to theory. While this mirrors reality, in that the theory of profit sharing is not well developed, it is somewhat disappointing that such a well-qualified author makes so little attempt to advance the theory of profit sharing.

In my view, the most important contribution of this book is the exhaustive analysis of existing empirical evidence, and the identification of the difficulties in doing empirical research in this area. Reading this book certainly makes the reader aware that much more research needs to be done before the question posed in the book title can be definitively answered. It also brings us up to date on where we are now, and the key issues that still need resolution, and is therefore "must" reading for researchers in the field.

Richard J. LoNG

University of Saskatchewan

La gestion des organisations publiques, par Harold F. GORTNER, Julianne MAHLER et Jeanne Bell Nicholson, Sainte-Foy, Les Presses de l'Université du Québec, 1994, 587 p., ISBN 2-7605-0739-4 (traduit et adapté par Albert Dumas et Daniel Maltais).

Il est rare que l'on puisse dire d'un manuel d'introdution à une discipline scientifique que c'est un beau livre. C'est le cas de ce manuel. En le refermant, $j$ 'avais acquis la conviction que le management enseigné à partir des théories de l'organisation applicables uniquement aux entreprises privées ou à but lucratif procure aux étudiants une formation incomplète, sinon tronquée. Les auteurs se donnent pour objectif de faire découvrir que les organisations publiques gouvernementales - particulièrement la fonction publique - ont leur spécificité propre. La plupart des chercheurs ont jusqu'à maintenant trop ignoré ce problème parce qu'ils ont pris pour acquis que les principes traditionnels de management avaient une valeur universelle. «Ils se sont attardés, disent les auteurs, sur la stabilité, la rationalité et l'efficacité et ont pratiquement évacué de leurs analyses l'instabilité, le pouvoir et les conflits ".

Il ne faut donc pas voir la fonction publique comme une bureaucratie fossilisée. Un tel jugement peut provenir du fait qu'elle est d'abord chargée d'administrer les lois, que le devoir de rendre des comptes (l'imputabilité) y joue un grand rôle et que l'administration est subordonnée à la loi. À propos de cette dernière caractéristique spécifique, un fonctionnaire public faisait remarquer à l'un des auteurs que dans le cas d'un gestionnaire d'une organisation privée, le message est : «Vas-y jusqu'à ce que je te dise d'arrêter » alors que dans le cas d'un gestionnaire public, le message est : «N'y vas pas 